\title{
Significant Dates in the \\ Life of Thomas Jefferson
}

1743

1760

1762

1767

1769

1772

1775-1776

1776-1779

$1779-1781$

1782

1783

1784

1785-1789

1790-1793

1794-1796

1797-1801

1801-1809

1809

1814

$1816-1818$

1818

1818

1819

1825

1826
Born at Shadwell, Albemarle County, Virginia, April 2

Entered William and Mary College, March

Graduated from William and Mary College, April

Admitted to the Virginia bar

Elected a member of the House of Burgesses of Virginia

Married Martha (Wayles) Skelton, January

Member of the Continental Congress

Member of the House of Delegates of Virginia; reported educational reform bills

Governor of Virginia

Mrs. Jefferson died, September

Member of the Continental Congress

Appointed as a negotiator to assist Benjamin Franklin in Paris, May

United States Minister to France

Secretary of State

In retirement at Monticello

Vice-President of the United States

President of the United States

Again in retirement at Monticello, March

Elected Trustee of Albemarle Academy

Made second attempt to establish a system of schools in Virginia

Bill authorizing a state university passed by Virginia legislature, February 21

Report of Commissioners to fix a site for the university (Rockfish Gap Report), August

Rector of the University of Virginia

University of Virginia opened, March

Died at Monticello, July 4 
